\title{
Research on College-Enterprise Cooperation Mechanism on Vocational Colleges
}

\author{
Qinghong Hu \\ Jilin Engineering Normal University, Changchun, Jilin, 130052
}

Keywords: cultivation mechanism; clothing specialty; vocational colleges

\begin{abstract}
College-enterprise cooperation has become an inevitable trend in the development of vocational education. However, in the current college-enterprise cooperation, the vocational colleges are highly motivated, the participation of enterprises is low, and the participation of enterprises in cooperative projects is not enough. Through the questionnaire survey of 96 enterprises in Shandong Province, this paper analyzes the current situation of college-enterprise cooperation, the willingness of cooperation between enterprises and vocational colleges, the factors affecting the enthusiasm of enterprises to participate in vocational education, and proposes mechanism recommendations to build a college-enterprise cooperation in higher vocational colleges.
\end{abstract}

\section{Introduction}

School-enterprise cooperation has become an inevitable trend in the development of vocational education. To deepen the teaching reform of higher vocational education and promote the innovation of teaching management system and mechanism, we must focus on building a mechanism for school-enterprise cooperation. However, from the current situation of school-enterprise cooperation, colleges and enterprises, as two organizations of different natures, have significantly different goals, structures, management and tasks. As the talent supply and demand side, there are different values judgments and deviations of concept consciousness, and this deviation should be minimized in the process of mutual participation in the cultivation of high-skilled personnel. As a researcher and practitioner of higher vocational education, it should analyze the participation and influencing factors of enterprises' participation in vocational education from the perspective of enterprises, and understand and analyze the willingness, behavior rules and needs of enterprises to participate in vocational education. This will help to improve the quality of talent training, and play a positive role in reference for the formulation of corresponding policies and systems, the choice of cooperation methods for colleges and institutions, and the training model for talents.

\section{The Status Quo of College-Enterprise Cooperation and Development in Higher Vocational Colleges in China}

In the mid-1980s, school-enterprise cooperative education was introduced into China, and gradually penetrated into China's higher vocational education. The close cooperation between "higher education" and "industrial sector" began to become the biggest feature of higher vocational education in China. Under the guidance of the government's support policies, China's higher vocational colleges have carried out an active school-enterprise cooperation model exploration, forming a road of cooperation and cooperation between schools and enterprises with Chinese characteristics.

Since China is completely different from the university-running system in the West, the development of school-enterprise cooperation in higher vocational colleges in China is more reflected in the "government-driven" model rather than the typical "market-driven" model in the West. Based on the policy guidance of the Chinese government on school-enterprise cooperation, the development of school-enterprise cooperation in China can be attributed to three basic stages.

At the beginning of the 21st century, it is a high-speed development stage of school-enterprise 
cooperation in higher vocational colleges in China, mainly reflected in the unprecedented policy support of the government and education authorities for the cooperation between schools and enterprises in higher vocational colleges. In the No. 2 Document of the Higher Education Department (2000) of the Ministry of Education, it is clearly stated that "the combination of industry and education" is one of the six basic characteristics of higher vocational education. In 2001 and 2002, the State Council organized two national "production, study and research" experience exchange meetings, and in 2002 issued the "Decision of the State Council on vigorously promoting the reform and development of vocational education” The policy document emphasizes that employment-oriented higher education reform should be combined with the development of vocational education, further expand the scale of vocational education, and enhance the ability to serve the economy and society. In the same year, a number of "production-study combination" research and construction projects were launched. The nationwide integration of industry, higher education and higher vocational education is booming. In 2005, the State Council issued the programmatic document of the "Decision of the State Council on Vigorously Developing Vocational Education", clearly requiring that the work-study combination and school-enterprise cooperation training mode be vigorously promoted, and that the internship training time for higher vocational college students should be no less than half a year. .

The perfect stage of school-enterprise cooperation in higher vocational colleges in China is marked by the proposal and implementation of the national demonstration higher vocational college construction plan. In November 2006, Minister Zhou Ji clearly pointed out at the video conference of the National Model Higher Vocational College Construction Plan that "the main task of higher vocational education in China will be to strengthen the connotation construction and improve the quality of education in the coming period"; November 2006, Education The "Opinions on Comprehensively Improving the Teaching Quality of Higher Vocational Education" issued by the Ministry summarized a series of experiences and lessons learned from the teaching reform of higher vocational education in the past 10 years, especially in the in-depth study on the key issues of improving the quality of school-enterprise cooperation. In November 2006, the Ministry of Education and the Ministry of Finance jointly launched the National Demonstration Program for Higher Vocational Colleges, and proposed to take professional construction as the core, with the school-enterprise cooperation and the combination of work-study and talent training as the entry point, and adhere to the principle of service. With employment as the orientation, take the road of production and learning combined with development, and comprehensively improve the overall level of model institutions. In the short period of time, the above-mentioned initiatives have aroused the enthusiasm of the school-enterprise cooperation of higher vocational colleges and related enterprises, and achieved fruitful results. In 2006, the first batch of 28 institutions established by the state closely contacted industry enterprises, and cooperated with enterprises to jointly develop courses and build training bases, including 5,334 off-campus practice bases, and employed 5,394 industrial enterprises and technical backbones. Skilled craftsmen are part-time teachers; 5,009 companies have signed cooperation agreements with these institutions, receiving a total of 237,000 internship students and 35,000 employment graduates.

\section{The Dilemma of College-Enterprise Cooperation and Development in Higher Vocational Colleges in China}

The continuous development of school-enterprise cooperation depends on the higher vocational colleges and enterprises to achieve their respective interests in cooperation. Win-win is the lifeline of cooperation between the two sides. Whether or not this win-win goal can be achieved depends on whether the results of the cooperation are recognized by the market, or whether the two parties determine whether they can cooperate based on market demand. This is also the experience of school-enterprise cooperation in Western developed countries. However, the school-enterprise cooperation environment of higher vocational colleges in China is fundamentally different from that of the West. The biggest difference is reflected in the role of the government. That is, the school-enterprise cooperation in China is essentially political, school, and enterprise cooperation. 
The particularity of the school-enterprise cooperation system in China determines that the school-enterprise cooperation under the guidance of the market economy faces two major difficulties in the short-term.

At present, the biggest reality of school-enterprise cooperation in higher vocational colleges in China may be that the "profit driving force" of enterprises participating in cooperation is low, and school-enterprise cooperation is "re-shaped and light". From a practical point of view, most enterprises that cooperate with schools and enterprises believe that school-enterprise cooperation cannot increase or significantly increase the profits of enterprises. The real reason for this result lies in the conflict between different operating mechanisms of universities and enterprises. For colleges and universities, although after years of education system reform, colleges and universities are becoming the main body of education, but the government as a major investor in colleges and universities still plays a decisive role in the management of colleges and universities. In the current university management, the government's mandatory management mechanism is still more reflected. It has obvious official colors from professional settings, educational goals, and curriculum settings. Although the school-enterprise cooperation driven by "command" can strengthen the initiative of the government and even universities in the school-enterprise cooperation, and grasp the direction of school-enterprise cooperation, it also objectively ignores the lack of reasonable returns in cooperation between cooperative enterprises, to a certain extent. It has hit the enthusiasm of enterprises to participate in school-enterprise cooperation.

From the successful experience of the West, relying on the market, the government through the legal system to ensure the legitimate and reasonable return of profits in the school-enterprise cooperation is an effective way. However, in China's relevant laws on school-enterprise cooperation, more emphasis is placed on the development orientation of school-enterprise cooperation, and there is a lack of operational corporate interest protection mechanisms. For example, the State officially implemented the Vocational Education Law on September 1, 1996. However, in the specific implementation, few local governments will formulate specific implementation regulations within the scope of the Vocational Education Law to regulate and guide higher vocational education. The school-enterprise cooperation, which makes the lack of effective school-enterprise cooperation guarantee mechanism from the legal level.

\section{Mechanism Innovation in the Practice of College-Enterprise Cooperation in Higher Vocational Colleges in the New Period}

After more than 20 years of development, the school-enterprise cooperation system in China has greatly improved the mode of school-enterprise cooperation, the number of cooperative enterprises, and the number of personnel training in school-enterprise cooperation. However, from the perspective of the school-enterprise cooperation system, the government-led diversified cooperation system has not achieved breakthroughs, and it is increasingly becoming an obstacle to the further development of school-enterprise cooperation in higher vocational colleges in China. The government-led leadership has made it impossible for colleges and universities to independently seek cooperative projects and cooperation targets that are most suitable for the development of the school itself, and has also hampered the enthusiasm of cooperation. To change the government-led cooperation system, the root cause lies in changing the government's status as the sole investor of the university and realizing the diversification of the school-enterprise cooperation investment system. Therefore, exploring a diversified new school-enterprise cooperation system is one of the core tasks of school-enterprise cooperation mechanism innovation. Through the establishment of a diversified school-enterprise cooperation system, based on the capital contribution relationship, the rights and obligations of all parties to the cooperation can be clarified, and the scientific and timely decision-making can be realized, and the cooperative interests of all parties can be fully protected.

The "school-enterprise" cooperation level is shallow, and the low level of incentives and constraints on the interests of enterprises is the biggest bottleneck in the development of school-enterprise cooperation in higher vocational colleges. The first condition for solving this problem is to establish a reasonable interest distribution mechanism. Only attractive interests can 
make enterprises not only regard school-enterprise cooperation as a kind of social responsibility, but a lucrative temptation. How to make enterprises and universities form an interdependent and mutually reinforcing symbiotic relationship in cooperation is the key to break through this bottleneck. Therefore, the formation of embedded relationships between enterprises and universities is particularly important. The school-enterprise cooperation model is also a new trend in the school-enterprise cooperation development model. The so-called two-way embedded type is the cooperation mode in which the school is embedded in the enterprise, and the enterprise is embedded in the school. The school and the enterprise "you have me, I have you", and the "school in the factory" and "factory middle school" are built to realize resource sharing. Complementary advantages, shared risks, and common interests. Co-construction The "training base" is the carrier of "two-way embedding" between school and enterprise cooperation.

After years of exploration, the effectiveness of the "two-way embedded" school-enterprise cooperation model has begun to appear. Funding construction by the college, providing venues, introducing brand, technology and management experience of the company, and building a cooperative training base in the school has become one of the new trends in school-enterprise cooperation in the future. The embedded cooperation mode has changed the basic form of "investment" and "benefit" of enterprises in the traditional cooperation mode. School-enterprise cooperation is no longer just "social responsibility" for enterprises, and has obvious benefits and predictability. At the same time, enterprises have invested soft investment in brand, technology and management experience in cooperation with universities.

\section{Conclusion}

At present, the school-enterprise cooperation in higher vocational colleges in China is still in its infancy. After sorting and summarizing, we can find that the cooperation between schools and enterprises in higher vocational colleges is a complex system, and the problems exist in all aspects of the system. Therefore, only through the full play of the functions of schools, enterprises and governments from concept to practice can we promote the development of school-enterprise cooperation in higher vocational colleges to a deeper level.

\section{Acknowledgements}

Fund Project: Research on Cooperative Cultivation Mechanism of Clothing Specialty in Vocational Colleges

\section{References}

[1] Ding Jinchang, Tong Weijun, Huang Zhaoxin. Innovation of the Operational Mechanism of Higher Vocational School-Enterprise Cooperation [J]. Educational Development Research, 2016 (17).

[2] Zhu Chunhui. Problems and Countermeasures in School-Enterprise Cooperation in Higher Vocational Colleges [J]. Education and Occupation, 2016 (30).

[3] Zhang Ke. Problems and Countermeasures in School-Enterprise Cooperation Development Planning [J]. Mechanical Vocational Education, 2014 (4).

[4] Hu Yanzhen, Cao Lisheng, Liu Yonghong. Research on the bottleneck and countermeasures of school-enterprise cooperation in higher vocational education in China [J]. Higher Education Exploration, 2013 (1). 